\title{
Study of Membrane Fouling and Trihalomethane Formation in Reverse Osmosis Desalination Pilot Unit
}

\section{Benamar DAHMANI and Mustapha CHABANE*}

Spectrochemistry and structural pharmacology laboratory, Department of chemistry, Science faculty, University of Tlemcen, ALGERIA

\begin{abstract}
The objective of this research is to study the combined effect of natural organic matter of benisaf sea water (west of Algeria) on the trihalomethane formation and reverse osmosis membrane fouling.

The chlorination method for disinfection of sea water in the pre-treatment step is widely used on several RO desalination plants, which present a disadvantage such as the trihalomethane produced caused by the reactivity of natural organic matter with chlorine.

The THM formation on pretreated feed sea water and permeate will be also evaluated by monitoring using several parameters such as Total organic carbon (TOC), Specific ultraviolet visible absorption (SUVA), Ultraviolet absorption at $254 \mathrm{~nm}\left(\mathrm{UV}_{254}\right)$.

Reverse osmosis pilot plant unit has been chosen to determine the membrane fouling will be determined using ATR-FTIR spectra of clean and fouled membrane and atomic force microscopy (AFM) to assess the membrane fouling.
\end{abstract}

Keywords: Natural organic matter (NOM); Fouling; Reverse osmosis (RO); Chlorination; Trihalomethane (THM).

\section{Introduction}

Natural organic matter (NOM) is complex mixture of organic materials and contains aromatic and aliphatic macromolecules. Each fraction represents different molecular weights, charge densities and structures (hydrophobic, transphilic and hydrophilic). NOM molecular weight and hydrophobicity are also found to influence NOM adsorption strongly.

Fouling is essentially caused by the deposition of foulants on the membrane surface, causing deterioration in the membrane performance through a decline in the flux and an increase in the membrane resistance.

Results of degradation of the organic materials, generated by physical, chemical and biological activities both in the watershed surrounding a water source and within the water source itself it can be basically divided as humic and non-humic substances. Generally humic substances include hydrophobic fractions whereas non humicsubstances involve hydrophilic fractions which are low molecular weight carbohydrates, proteins and amino acids [1]. NOM is known to be a precursor to the formation of DBPs such as trihalomethanes (THMs), haloacetic acids (HAAs) which are known as potentially harmful disinfection by-products (DBPs). Therefore to understand the fractionation of NOM from water sources has recently gained great attention.

Chlorine commenly is used as disinfectant in sea water desalination plant in Algeria At pre-treatment , chlorine reacts with the presence of NOM in water source and it causes formation of disinfection byproducts (DBPs), such as trihalomethanes (THMs) [2]. When the organic load is higher in chlorinated water, DBPs concentrations will be higher because of chlorine reaction with natural organic matter (NOM) to form disinfection by products (DBPs). Humic materials in surface waters tend to have a significant content and are in hydrophobic groups. One of the important sources for DBPs is acidic fraction of hydrophobic groups which are generally dominant [3]. As a consequence, during preoxidation step water contains higher loads of organics thus the formation of chlorinated DBPs, such as trihalomethanes (THMs) and haloacetic acids (HAAs), is favoured. The epidemiological studies demonstrated that trihalomethanes (THMs) are potentially harmful to human health [4]. Thus, many developed countries set the maximum contaminant level (MCL) for trihalomethanes (THMs), i.e. $80 \mu \mathrm{g} / \mathrm{L}$ in USA, $250 \mu \mathrm{g} / \mathrm{L}$ in Australia, $100 \mu \mathrm{g} / \mathrm{L}$ in European Community (EC) and $10 \mu \mathrm{g} / \mathrm{L}$ in Germany.

The aim of this study is to determine the changes in NOM that affect THM formation and to elucidate the differences in organic matter content either as SUVA followed by the respective THM formation potentials (THMFP) after chlorination of benisaf sea water. In this context, raw water, chlorinated water and permeate were compared in terms of the parameters that are specific to organic matter content such as DOC, $\mathrm{UV}_{254}$, SUVA and THMFP.

\section{Materials and Methods}

\section{Water source}

The results of benisaf sea water analysis of the important parameter in relation to this study will be presented on the Table 1 .

\section{RO membrane characteristics}

The RO membrane used in this study was designed by manufacturer

*Corresponding author: Mustapha CHABANE, Spectrochemistry and structura pharmacology laboratory, Department of chemistry, Science faculty, University of Tlemcen, ALGERIA; Tel: 21343213742; E-mail: chabanet2001@yahoo.fr

Received October 21, 2011; Accepted November 17, 2011; Published November 25, 2011

Citation: DAHMANI B, CHABANE M (2011) Study of Membrane Fouling and Trihalomethane Formation in Reverse Osmosis Desalination Pilot Unit. J Membra Sci Technol 1:110. doi:10.4172/2155-9589.1000110

Copyright: (C) 2011 DAHMANI B, et al. This is an open-access article distributed under the terms of the Creative Commons Attribution License, which permits unrestricted use, distribution, and reproduction in any medium, provided the original author and source are credited. 


\begin{tabular}{|l|l|l|}
\hline Parameter & Units & Average Values \\
\hline $\mathrm{pH}$ & - & 8.34 \\
\hline $\mathrm{DOC}$ & $\mathrm{mg} / \mathrm{L}$ & 5.587 \\
\hline TOC & $\mathrm{mg} / \mathrm{L}$ & 6.021 \\
\hline UV $_{254}$ & $\mathrm{~cm}^{-1}$ & 0.147 \\
\hline SUVA & $\mathrm{L} / \mathrm{mg} \cdot \mathrm{m}$ & 2.63 \\
\hline
\end{tabular}

Table 1: Benisaf sea water quality characteristics.

as SWC3 (Hydraunautics). It was made with polyamide thin film composite membrane configuration in spiral wound configuration :the size was outside diameter 1.5 inches and length 40 inches, salt rejection :99.6\%,the effective membrane surface is $370 \mathrm{ft}^{2}$, maximal feed flow 17 $\mathrm{m}^{3} / \mathrm{h}$,permeate feed flow $23 \mathrm{~m}^{3} / \mathrm{h}, \mathrm{SDI}=5$,maximum applied pressure $: 8,27 \mathrm{MPa}$.

\section{Pilot studies}

Experiment was conducted using a cross flow pilot reverse osmosis membrane unit shown on the Figure 1. After filtration of sea water through a filter of $0.45 \mu \mathrm{m}$, a dose of chlorine is added through a system for disinfection and then there the operation of coagulation and flocculation and phase separation by reverse osmosis as is shown in Figure1. Sea water feeds the system during a period of 6 months at different times of the year 2010.

\section{Analytical methods}

Sampling and preservation : During the study several samples were collected monthly from different sampling Experimental setup of RO Chlorination system the sampling contains raw water, filtrated water after one of the sand filters ; treated water with chlorine and permeate. The water sample was collected from March 2010 to September 2010 The samples were stored in $40 \mathrm{ml}$ vials and closed with Teflon lined screw cap, preserved with sodium thiosulfate $\left(\mathrm{Na}_{2} \mathrm{~S}_{2} \mathrm{O}_{3}\right)$ at $4^{\circ} \mathrm{C}$ until the analysis. All samples were measured between in 1 and 15 days after sampling. For kinetics experiments filtrated water (after one of the sand filters) were taken monthly from. Experimental set-up of RO Chlorination system.

The filtrated water was stored in $5 \mathrm{~L}$ plastic bottles at $4^{\circ} \mathrm{C}$ until the chlorination experiment and without adding any preservatives. In laboratory, kinetic experiments were carried out after the chlorination of the filtrated water samples [11].

Final or maximum THMs formation potential (THMFP) measurements were conducted in accordance with Standard Methods of $5710 \mathrm{~B}$ [8] with following principle Under standard conditions, samples are buffered at $\mathrm{pH} 7.0 \pm 0.2$, chlorinated with an excess of free chlorine, and stored at $25 \pm 2^{\circ} \mathrm{C}$ for $7 \mathrm{~d}$ to allow the reaction to approach completion. As a minimum, $\mathrm{pH}$ is buffered at a defined value and a free chlorine residual of 3 to $5 \mathrm{mg} \mathrm{Cl} 2 / \mathrm{L}$ exists at the end of the reaction time. THM concentration is determined by using liquid-liquid extraction according to EPA Methods 551.1 [9].

The sum of the four trihalomethanes(chloroform, bromodichloromethane, dibromochloromethane, and bromoform) mass concentrations was reported as Total THM in $\mu \mathrm{g} / \mathrm{L}$. Samples were analyzed by a Agillent Gas Chromatography (6890 Series) with an micro electron capture detector (GC-ECD), auto sampler and capillary column (J\&W Science DB-5.625), $30 \mathrm{~m}$ x $0.25 \mathrm{~mm}$ I.D.x 0.25 $\mu \mathrm{m}$ film thicknesses. $\mathrm{pH}$ measurements were carried out with a WTW$\mathrm{pH}$ meter TOC and DOC measurements were performed by using a Shimadzu TOC-5000 analyzer equipped with an auto sampler. The inorganic carbon $\left(\mathrm{H}_{2} \mathrm{CO}_{3}, \mathrm{HCO}_{3}^{-}\right.$, and $\left.\mathrm{CO}_{3}^{2-}\right)$ was removed by acidifying the sample to $\mathrm{pH}$ values between 2 and 3 with $1.0 \mathrm{~N}$ hydrochloric acid $(\mathrm{HCl})$ followed by sparging with $\mathrm{CO}_{2}$ free air. Thus, the measured Total or dissolved carbon is equal to respectively total organic carbon (TOC) or dissolved organic carbon (DOC). DOC was analyzed after filtration through a $0.45 \mu \mathrm{m}$ membrane filter.

In kinetics experiments beside THMs compounds also the chlorine ion concentration was measured calorimetrically according to standard method 8021 DPD method (powder pillow) for free chlorine determination and standard method 8167 DPD method (powder pillows) for total chlorine determination using a Hach Dr 2800 analyzer. A 25-ml cell was filled with samples and added DPDs free chlorine reagent (powder pillow). After mixing, chlorine ion concentration was read at $530 \mathrm{~nm}$ wavelength. Laboratory chlorination experiments were carried out monthly with filtrated water collected at the treatment plant. The experiments were conducted under two conditions: base line condition $\left(\mathrm{pH} 7 ; 21^{\circ} \mathrm{C}\right.$ and $2.5 \mathrm{mg} / \mathrm{l} \mathrm{Cl}_{2}$ ) to gain information about the change of the organic matter in the raw water [12-14].

UV254 absorbance measurements were performed in accordance with Standard Methods 5910 B [8] by using a Hach-Lange Dr 5000 spectrophotometer at a wavelength of $254 \mathrm{~nm}$ with $1 \mathrm{~cm}$ quartz cell. The samples were first filtered through a pre-washed $0.45 \mu \mathrm{m}$ membrane filter to remove turbidity, which can interfere with this measurement. SUVA shows us the humic content of water. It is defined as the UV absorbance at $254 \mathrm{~nm}\left(\mathrm{~m}^{-1}\right)$ divided by the concentration of dissolved organic carbon ( $\mathrm{mg} \mathrm{C} / \mathrm{L})\left(\mathrm{UV}_{254} / \mathrm{DOC}\right)$. The unit of SUVA is commonly

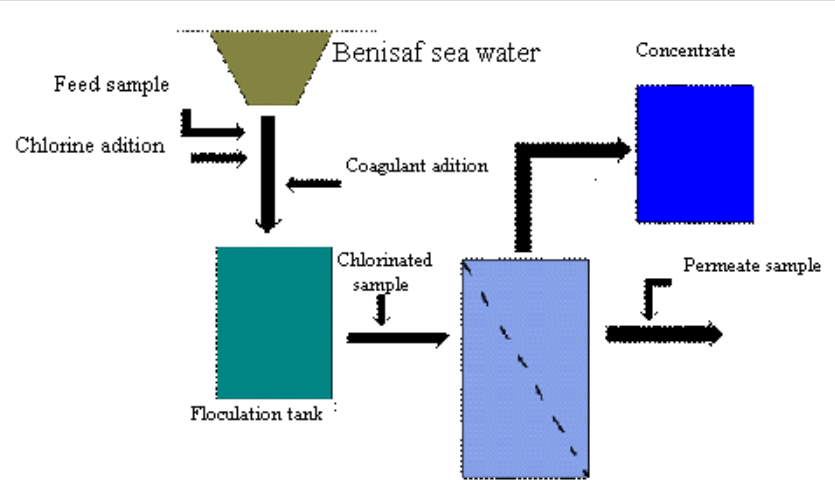

Figure 1: Experimental set-up of RO Chlorination system.

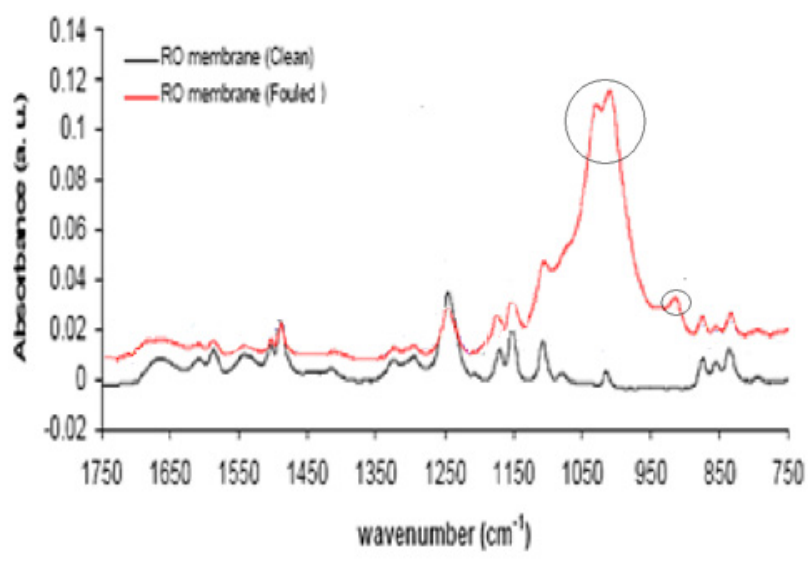

Figure 2: FTIR spectra of clean and fouled membrane. 
expressed as $\mathrm{L} / \mathrm{mgC} \mathrm{m}$. The $\mathrm{RO}$ membrane autopsy will be established after 6 months.

\section{ATR/FTIR spectroscopy analysis}

The ATR/FTIR spectroscopy was proven to be a valuable tool for studying membrane fouling by natural water $[8,9]$.the FTIR spectrum of $\mathrm{RO}$ membrane clean and fouled in this study was shown on the Figure 2.

The contaminants were located at 993,1015 and $1054 \mathrm{~cm}^{-1}$, while all the high absorption band of clean RO membranes was located in the amide and carbohydrates regions $\left(750-1750 \mathrm{~cm}^{-1}\right)$. The spectra of a clean RO membrane and fouled and clean RO membrane show similar spectral patterns

The high absorption bands in the region between 1100 and $900 \mathrm{~cm}^{-1}$, suggest that the membrane foulants include polysaccharides or silica colloids

\section{Atomic force microscopy}

Micro topographical images of the membrane surfaces were captured by an atomic force microscope (AFM) to assess the rate of membrane fouling. Analyses of the micro topographical images indicate that contamination of the membrane surface begins immediately during the filtration process.

The contamination consist on bacterial bio film (bio fouling) due to the bacterial substance and organic matter.

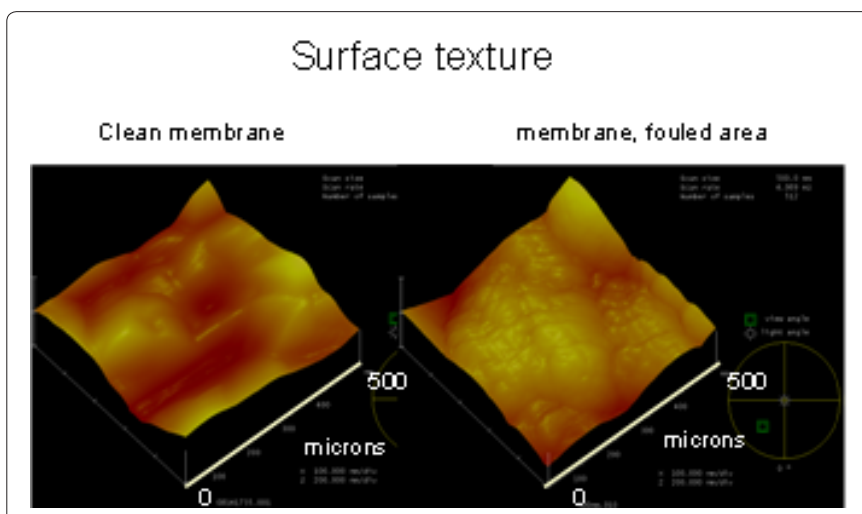

Figure 3: The AFM characterisation of clean and fouled membrane.

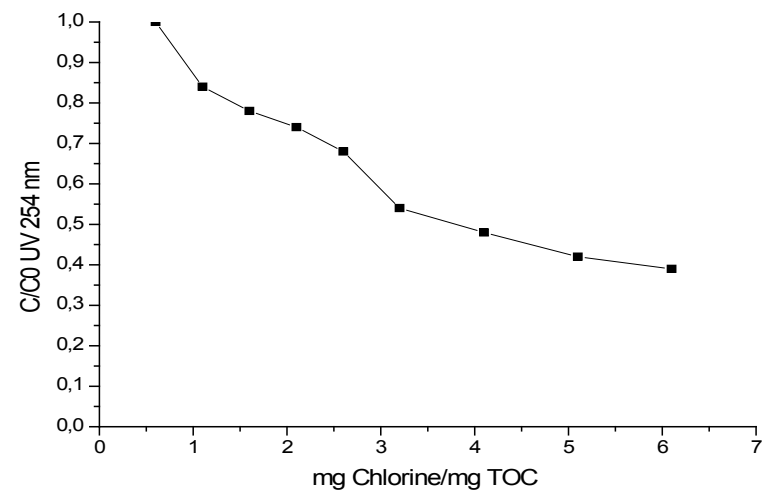

Figure 4: Relationship between $\mathrm{mgCl}_{21} \mathrm{mg} \mathrm{TOC}^{-1}$ of Chlorine dosage and UV at $254 \mathrm{~nm}$.

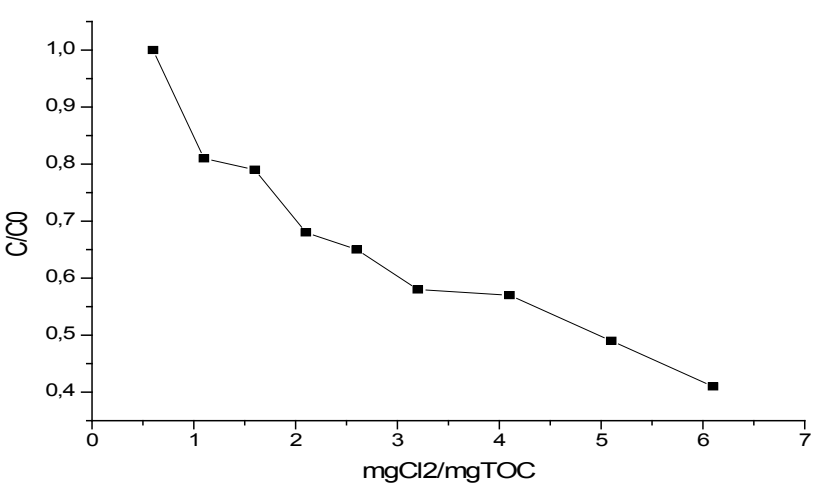

Figure 5: Relationship SUVA values and Chlorine dosages.

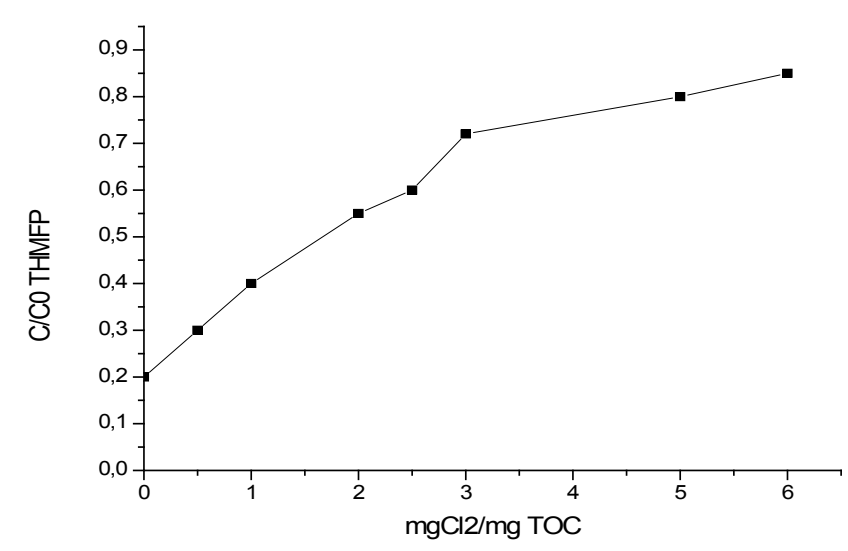

Figure 6: Residual THMFP according to chlorine dosage.

\section{Results}

$\mathrm{UV}_{254}$ absorption is commenly used an index of the aromatic level. Figure 4 demonstrates increased chlorine dosage up to $6.1 \mathrm{mgCl}^{2}$ $\mathrm{mgTOC}^{-1}, \mathrm{UV}_{254}$ absorption was lowered by about $0.06 \mathrm{~cm}^{-1}$.

This reduction indicates the breakdown of some conjugated carbon structures leading to the fragmentation of high molecular weight organic substances into smaller units. The higher percent removals were obtained at the higher chlorine dosages compared to the values observed at lower chlorine dosages.

SUVA shows that the humic contents of water. Reduction in SUVA is attributed to removal of humic substances according to chlorine dosage. Figure 5 shows the reduction of SUVA as a function of $\mathrm{mgCl}_{2}$ mg TOC ${ }^{-1}$ of chlorine dosage. The reduction of SUVA is related with chlorine dosage. Increasing chlorine dosage gives better destruction aromatic structure of organic matter and results in reduction of SUVA values. When chlorine dosage increased $0.5 \mathrm{mgCl}_{2} \mathrm{mg} \mathrm{TOC}^{-1}$ to 6.1 $\mathrm{mg} \mathrm{Cl}_{2} \mathrm{mg} \mathrm{TOC}^{-1}$, SUVA of Benisaf sea water reduced respectively 13 $\%$ and $48 \%$. Maximum reduction of it about observed as $60 \%$ at 6.1 $\mathrm{mgCl}_{2} \mathrm{mg} \mathrm{TOC}^{-1}$. This trend is similar to observed on $\mathrm{UV}_{254}$ data in this experimental study.

Figure 6 shows the increases of concentration of THMFP values of Benisaf sea Water according to applied chlorine dosages. Increasing Chlorine dosage gives higher THMFPdosage, THMFP was increases about $16 \%$, this sharp decrease go on till $41 \%$ at $6.1 \mathrm{mgCl}_{2} \mathrm{mg} \mathrm{TOC}^{-1}$. The maximum THMFP increases was determined at $6.1 \mathrm{mg} \mathrm{Cl}_{2} \mathrm{mg}$ $\mathrm{TOC}^{-1}$ as $57 \%$. 


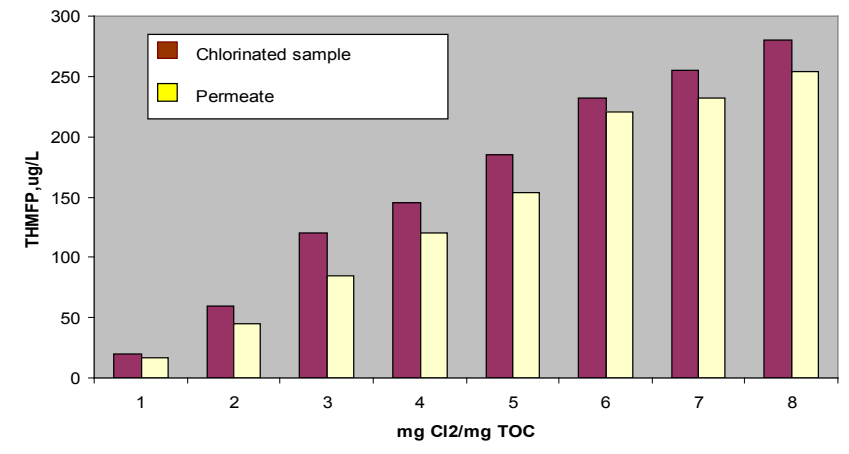

Figure 7: Relationship THMFP to chlorine dosage.

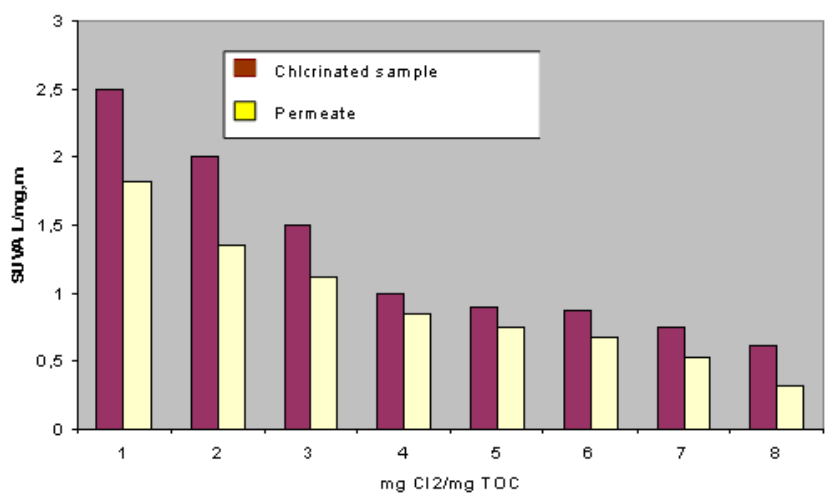

Figure 8: Relationship SUVA related to chlorine dosage.

At this time SUVA and $\mathrm{UV}_{254}$ reductions were $64 \%$ and $60 \%$.

SUVA, the ratio of $\mathrm{UV}_{254}$ to DOC, is precursor of Trihalomethane Formation Potential. THMFP and SUVA change related with chlorine dosage as shown in Figure 8. At the beginning of chlorination the THMFP concentration is $262 \mu \mathrm{g} / \mathrm{L}$ and applied chlorine dosage was increased to $6.1 \mathrm{mgCl}_{2} \mathrm{mgTOC}^{-1}$, THMFP concentration increase $242 \mu \mathrm{g} / \mathrm{L}$, about $92 \%$ reduction. Here, SUVA also increased $38 \%$. Occurrence of THM is related with SUVA value very much. Chlorine reacts with NOM and decrease aromatic fraction of NOM, the other words SUVA, resulting in significant increases in THMFP. NOM is the precursor in the formations of the THMs. The increase of chlorine dosages give degradation of aromatic structure of organic substances and so decrease THMFP. The higher increase in THMFP relative to DOC was also observed by other researchers about chlorination studies on various surface waters.

The rejection of THM by reverse osmosis membrane is comprised between $10 \%$ at $0.5 \mathrm{mg}$ of $\mathrm{Cl} 2 / \mathrm{mg}$ TOC and decrease to $7.35 \%$ at 6.1 $\mathrm{mg}$ of $\mathrm{Cl}_{2} / / \mathrm{mg}$ TOC.

The decreasing values of THM rejection is due also to the effect of membrane fouling and the lower efficiency of THM rejection by reverse osmosis membrane.

\section{Conclusion}

When chlorination applied to benisaf sea water, organics in terms of $\mathrm{UV}_{254}$ or SUVA are significantly reduced. Chlorination could convert NOM from humic substances to non-humic fractions and from higher- to lower-molecular weight fractions. After Chlorination of benisaf sea water, a greater decrease is observed in the percentage of the $\mathrm{UV}_{254} \% 60$ SUVA $64 \%$ and increases of THMFP $92 \%$. The use of chlorination on the pre-treatment give higher formation potential of THM related to destruction of aromatic structure of organic matter. The higher percent formations were obtained at higher chlorine dosages compared to the values observed at lower chlorination dosages for benisaf sea water.

The effect of organic compound as polysaccharide and silica will be improved by FTIR, this analysis will be confirmed by the AFM characterisation.

The lower rejection of THM by reverse osmosis membrane is related to the efficiency of reverse osmosis membrane the decrease of THM rejection at higher concentration of chlorine is due also to the foulant compounds wich block the passage of trihalomethane trough the RO membrane

\section{References}

1. Steelink C (1977) Humates and other natural organic substances in the environment, J. Chem. Educ 54: 599-603.

2. H.C. Hong a, Y. Liang a, B.P. Han b, A. Mazumder c, M.H. Wong (2007) Modeling of trihalomethane (THM) formation via chlorination of the water from Dongjiang River (source water for Hong Kong's drinking water): Sci Total Environ 385: 48-54.

3. Iriarte-Velasco U, Álvarez-Uriarte JI, González-Velasco JR (2007) Removal and structural changes in natural organic matter in a Spanish water treatment plant using nascent chlorine, Separation and Purification Technology, 57: 152160.

4. Bull RJ, Birnbaum LS, Cantor KP, Rose JB, Butterworth BE, et al. (1995) Wate Chlorination: Essential Process or Cancer Hazardous, Fundam Appl Toxicol 28: $155-166$.

5. Kurama H, Poetzschk J, Hasenede R (2002) The application of membrane filtration for the removal of ammonium ios from potable water, Water Res 36 2905-2909.

6. (1998)Standard Methods for the Examination of Water and Wastewater American Public Health Association 20: APHA/AWWA/WPCF Washington DC

7. USEPA (1990) National Primary Drinking Water Regulations: Dinsinfection/Disinfection By-Products (D/DBP) Rule Federal Register 59: 38668.

8. Iriarte-Velasco U, Álvarez-Uriarte JI, González-Velasco JR, (2007) Remova and structural changes in natural organic matter in a Spanish water treatment plant using nascent chlorine, Separation and Purification Technology 57: 152160

9. ANTS Infrared Spectroscopy: Fundamentals and Applications Wiley. 